\title{
The Ethical Turn of the Rule of Law in the Global Environment under the Influence of the Concept of a Community of Shared Future for Mankind
}

\author{
Chunlin Li, Jianqing Chen* \\ Law School, Fuzhou University, Fuzhou, China \\ Email: *aaronpower@foxmail.com
}

How to cite this paper: Li, C. L., \& Chen, J. Q. (2019). The Ethical Turn of the Rule of Law in the Global Environment under the Influence of the Concept of a Community of Shared Future for Mankind. Beijing Law Review, 10, 98-114. https://doi.org/10.4236/blr.2019.101006

Received: December 29, 2018

Accepted: January 30, 2019

Published: February 2, 2019

Copyright ( 2019 by author(s) and Scientific Research Publishing Inc. This work is licensed under the Creative Commons Attribution International License (CC BY 4.0).

http://creativecommons.org/licenses/by/4.0/

\section{(c) (i) Open Access}

\begin{abstract}
Environmental law is a department law which has the biggest demand for ethics, and it is the only department law with endless pursuit of ethics. In a sense, the motive force of human protection of the environment and pollution prevention comes from environmental ethics. In other words, environmental governance begins with the generation of environmental ethics. However, with the development of science and technology, man's desire to conquer nature has been becoming stronger and stronger, which makes environmental ethics and environmental rule of law go through different degrees of integration in different periods. In the 21st century, with the global economy and environment under the influence of the global financial crisis, the global environmental problems have become more and more serious, and people are more and more aware of the importance of environmental ethics to global environmental governance. The concept of a Community of Shared Future for Mankind advocated by Chinese President Xi Jingping is at the right time to play its important role. It will guide the ethical dilemma of the global environmental rule of law in the new period with a broader environmental ethical vision, and will inevitably lead to a new ethical turn of environmental rule of law.
\end{abstract}

\section{Keywords}

Environmental Ethics, a Community of Shared Future for Mankind, Global Environment, Environmental Rule of Law

\section{Introduction}

Since the global financial crisis, uncertainties in the development of the world 
economy have increased. For the sake of their own development, regardless of the environmental problems of other countries, some countries have increasingly deviated from international environmental justice and evaded their due international environmental responsibilities. They do not understand that the entire earth's environmental problems are interconnected as a whole, and do not work with the international community to deal with global climate governance and other issues.

The international community is facing the problem between economic development and environmental governance such as climate change. Because of this, the international community is often divided over the governance of climate change, and it is difficult to have a more satisfactory solution. Under such a background, it is very important to find a kind of environmental ethics which can adapt to that. Environmental ethics is how human beings satisfy the requirements or value of the existence of the environment after the environment meets the needs of human existence, and at the same time, human beings meet their own higher level of civilization needs. It is the spiritual guarantee to realize the harmony between man and nature. And it is the summary of human experience in the long process of practice, which is established to coordinate the relationship between human beings and the natural environment and to restrain human behavior. ${ }^{1}$ Environmental law needs ethics because it is blind without values. ${ }^{2}$ Chinese President Xi Jinping's proposal to adhere to the road of peaceful development and promote the construction of a Community of Shared Future for Mankind characterized by the common destiny of human beings is a sublimation of environmental ethics in the new historical period. It aims at taking into account the legitimate concerns of other countries in pursuing its own interests and promoting the common development of all countries in the pursuit of its own development. We human beings have only one earth, and all nations live together in one world. We should advocate the consciousness of a Community of Shared Future for Mankind. The global values of a Community of Shared Future for Mankind include the view of interdependent international power, the view of common interest, the view of sustainable development and the view of global environmental governance. It is of great practical significance to regard a Community of Shared Future for Mankind as the environmental ethics to guide the global environmental rule of law in the international community.

Since the global financial crisis, the world economic growth rate has slowed down with weak recovery of the market demand. The tendency of global trade protectionism is increasing day by day. Many countries adopt various trade protection policies and measures one after another. In addition to anti-dumping, countervailing, tariff barriers and other traditional means of trade protection, non-tariff barriers, intellectual property protection and other forms of trade protection are more frequently seen. New forms of trade protection means and

${ }^{1}$ http://news.sina.com.cn/c/2005-07-11/06096401012s.shtml (accessed on 10 Jan. 2019).

${ }^{2}$ See Taylor, supra note 69 , at 25-52. 
measures, such as export incentives, government subsidies and localization requirements, are emerging in an endless stream. And developed countries led by the United States are the promoters of trade protectionism. According to the data of the WTO, from 2008 to May 2016, the G20 members had imposed a total of 1583 new trade restrictions. Among them, the United States has imposed more than 600 restrictions against other countries and regions, accounting for about $40 \%$ of the trade restrictions of G20 members. ${ }^{3}$

Due to the weak recovery of the global economy, some countries, for the sake of their own GDP growth, emphasize the importance of trade surplus from their own self-interests, but do not turn to the problems of trade deficit from more essential aspects. Therefore, they, on the one hand, substantially increase import tariffs in an attempt to restrict imports; on the other hand, they vigorously develop domestic manufacturing in an attempt to increase GDP by exporting more goods to other countries based on unequal tariff preference. This concern for the interests of their own countries with the disregard of interests of other countries and the focus on the economic interests with the disregard of the environmental interests will not only inevitably add harm to the weak global economy but also aggravate the damage to the global environment.

With the increasing economic activities nowadays, the negative impact of what human beings do to nature is becoming more and more obvious. Some of the environmental problems are fatal to human beings. Since industrialization, human beings have been using fossil fuels extensively and cutting down forests in large areas, resulting in the increasing concentrations of greenhouse gases (carbon dioxide and methane etc.) in the atmosphere, the rise of global temperatures, the decrease of snow cover in the northern hemisphere and the faster melting of antarctic ice shelf. The sea level has been rising continuously in the past century due to the thermal expansion of sea water and the melting of glaciers (Liu et al., 2012).

In the context of global warming, the melting of polar and continental glaciers and thermal expansion of sea water could cause global sea levels to rise. The rise of sea level will aggravate the harm of extreme marine disasters, destroy the ecological environment near shores and increase the risk of inundation of islands, which will affect the economic and social development of coastal areas for a long time. Although sea level rise is a continuous and slow process, it will definitely contribute to the frequency and hazard of marine disasters.

Climate change is one of the major challenges facing the international community today. Global warming has increased the frequency of extreme weather such as hurricanes and extremely hot weather, and the rising sea level caused by climate change will also severely affect the lives of coastal residents. The exodus of people because of climate-related causes has given birth to a new term-climate refugees (Mao, 2014).

${ }^{3}$ Zhang, X. Current Global Trade Situation and Future Development Trend. Macroeconomic Management 2017 (7): 84-87. 


\section{The Quintessence of Environmental Ethics of a Community of Shared Future for Mankind}

\subsection{The International Influence of a Community of Shared Future for Mankind}

Chinese President Xi Jinping has a profound insight into the future and destiny of mankind and the development trend of the times, accurately grasp the basic trend of China-world relations, and puts forward on a series of important occasions a great initiative to build a Community of Shared Future for Mankind. It aroused a warm response from the international community. As a "China plan" to promote the reform of the international order and perfect global governance, the concept of a Community of Shared Future for Mankind is exerting a profound influence on global governance, including global environmental governance. The concept of a Community of Shared Future for Mankind is regarded as the environmental ethics of the new era. Therefore, it has the profound internal function to promote the global environmental rule of law.

Countries with different systems, types, stages of development are interdependent and mutually beneficial, forming a community of shared future. President Xi Jinping has mentioned the concept of a Community of Shared Future for Mankind more than 100 times on international and domestic occasions. In particular, on 18 January 2017, at the United Nations headquarters in Geneva, he delivered a keynote speech entitled Work Together to Build a Community of Shared Future for Mankind, in which he proposed building a Community of Shared Future for Mankind for a lasting peace, universal security and common prosperity, openness and inclusiveness, and a clean and beautiful world. ${ }^{4}$ For the first time, he accurately defined the meaning of a Community of Shared Future for Mankind. Then, in the report of the 19th session of national congress of the communist party of China, he systematically expounded the idea and aspiration of building a Community of Shared Future for Mankind. This is a new view and new understanding of the nature of the international system and its future development in the new era of socialist construction (Zhang, 2018).

Less than a month after President Xi Jinping delivered a speech on Work Together to Build a Community of Shared Future for Mankind at the United Nations headquarters in Geneva, on 10 February 2017, at its 55th session, the United Nations Commission for Social Development adopted by consensus the resolution entitled Social Dimensions of the New Partnership for Africa's Development, in which it called upon the international community to work together in a spirit of win-win cooperation and the building of a Community of Shared Future for Mankind to strengthen its support for economic and social development in Africa. On 17 March, the United Nations Security Council adopted a resolution on Afghanistan, stressing that regional cooperation should be promoted in a spirit of win-win cooperation in order to effectively promote security, stability and development in Afghanistan and the region, and build a

${ }^{4}$ http://www.xinhuanet.com//world/2017-01/19/c_1120340049.htm (accessed on 10 Dec. 2018). 
Community of Shared Future for Mankind. On 30 October, the 72nd United Nations General Assembly, in charge of the Committee on Disarmament and International Security, adopted two resolutions on the prevention of an arms race in outer space, both of which incorporated the important concept of a Community of Shared Future for Mankind. It seems that the international community is beginning to use the concept of a Community of Shared Future for Mankind as the main solution to the problems of international and regional peace and security, human rights and development, and international environmental security. As one of the global security issues, international environmental governance cannot be without the concept of a Community of Shared Future for Mankind as an ethical guide.

A Community of Shared Future for Mankind carries the aspirations of all nations for a better life and constitutes a basic expression of international human rights, such as the right to peace, the right to security, the right to survival, the right to development and the right to the environment. Therefore, as a new concept of human society, a Community of Shared Future for Mankind is not only the "China plan" for global environmental governance but also the "China plan" for international environmental rights protection.

\subsection{The Value Orientation of a Community of Shared Future for Mankind}

The connotation of a Community of Shared Future for Mankind is closely related to the 5000-year-old Chinese culture. It is the development and embodiment of the wisdom and insight of Chinese traditional culture in the modern environment. Chinese Confucianism emphasizes the "world view" of "we are family" and holds that "all the people of the world are brothers". This simple view of "international" order plays an important role in inheriting and enlightening the construction and development of the concept of a Community of Shared Future for Mankind (Zhang, 2018). International justice is the primary value orientation for the concept of a Community of Shared Future for Mankind.

International justice refers to the moral rules that confer rights and obligations on all countries. It consists mainly of two forms of justice. The first is equal justice. The second is distributive justice, also known as "substantive justice". No matter how "justice" is interpreted, it always explores how resources should be reasonably and fairly distributed among members of society (Brian, 2011). ${ }^{5} \mathrm{Just}$ as the individual justice, the absolutization of national equality justice tends to aggravate national inequality because of the differences in resources endowment and government capacity. Distributive justice therefore emphasizes that, for the security and prosperity of the international community, the rights and obligations of the powerful and the weak, the rich and the poor, the developed and the underdeveloped can be granted differently in some respects. This implies a po-

${ }^{5}$ Barry B. 2011. Theories of Justice. Translated by Sun, X, et al. Jilin People's Publishing House, 1-6. 
litical focus on safeguarding the sovereignty of weak countries and increasing their ability to participate in global governance; and for several powerful countries, limit some of their powers relatively. More favourable economic rights can be given to poor countries in terms of trade, resource development, financial support, technology transfer, etc. In the mean time, rich countries should be required to undertake more corresponding obligations.

The concept of a Community of Shared Future for Mankind contains the ethical principles of the community of common economic interest, common security and common political responsibility, among which, the community of common responsibility is the fundamental guarantee of the community of common interests and common destiny. This means that, as the most important international entity, a country must establish an important sense of responsibility. This responsibility naturally involves both internal and external responsibilities. As far as internal responsibility is concerned, it requires each country to adhere to a sustainable way of development without harming the development of other countries and the international community as a whole because of its own development. In the case of external responsibility, it also requires that every country must resist the temptation of maximizing power and interest, respect others, uphold peaceful development and win-win cooperation on the basis of equality and tolerance, and at the same time respect nature, protect the environment, and achieve the sustainable development of human society.

In addition, the concept of a Community of Shared Future for Mankind also contains the ethical principle of enlightened self-interest. To build a Community of Shared Future for Mankind requires the self-interest and the altruism of all countries in the world, and we cannot ignore the the common good that we have in the international community. China has always shown such sincere altruism in the practice of a Community of Shared Future for Mankind. China sincerely treats the neighboring countries, promotes the construction of Belt and Road, and sincerely benefits the fruits of China's development to the rest of the world. And China sincerely helps African countries to develop faster so that the African people can live a better life. China is taking efforts to make the peoples of the world understand and help each other in the process of realizing their dreams, which contains the ethical essence of a Community of Shared Future for Mankind.

\section{The Historical Evolution of the Relationship between Environmental Ethics and Environmental Legislation}

It is known to all that environmental law, as a new department law, has only a history of more than 40 years. In fact, however, laws of environmental protection have existed for thousands of years in human history. In this process, with the development and progress of social economy, environmental legislation and environmental ethics have been continuously combined and separated. From a macro perspective, there are roughly three stages. The industrial revolution from 
the mid-18th century can be regarded as the time point of the separation of environmental legislation and environmental ethics. Before the industrial revolution, human beings were in awe of nature due to the low level of productivity and the backwardness of science and technology. But in the industrial society, with the development of science and technology because of industrial revolution, people were keen to conquer nature; environmental ethics was separated from environmental legislation. Then, when it comes to the 21st century, the earth has been confronted with unprecedented environmental pollution, and people have begun to rethink the importance of environmental ethics.

\subsection{The Combination of Environmental Ethics and Environmental Legislation}

The topic of dialogue advocated by environmental ethics is a direct embodiment of the general interests. Environment is vital to all life on earth. If we lose the environment, we will lose our qualifications for survival, let alone enjoy other rights and interests. That is to say, we all depend on nature to survive and develop, however, the full outbreak of ecological crisis reinforces the problem in an extreme way (Li, 2014).

Before the industrial society, people in different historical periods might hold more or less different attitudes towards the environmental ethics. As far as China is concerned, generally speaking, it was going in an atmosphere of harmonious relationship between man and nature. Limited to the low level of productivity and the backwardness of science and technology at that time, mankind's understanding of nature was still in the obscurity stage. In that period, human beings basically deemed nature with reverence, paid great attention to protecting nature and was kind to nature.

China has a long history and its legal system has a long history as well. The laws and regulations on environmental protection in ancient China can be traced back to the Shang dynasty, so it may be the first country in the world with environmental protection laws. ${ }^{6}$ Around the 14th century BC, the Shang Dynasty, China had a legal provisions on environmental protection. According to what was written in Hanfeizi's Theory Collection, in Shang Dynasty, anyone throwing rubbish on the street would be cut off their hands. ${ }^{7}$ In the 11th century BC, the Western Zhou Dynasty also issued Laws for Disafforestation, which stipulated, "don't destroy the house, don't fill the well, don't cut down trees, don't hurt the livestock, if there are people who don't follow the law, he/she will be killed without mercy." By the Qin Dynasty, with the development of agricultural production, laws to protect natural resources were more stringent. According to the records of Yunmeng Qin Slips unearthed in Hubei Province, there were a series of regulations on the rational exploitation of forests, land, water flow, wildlife and other natural resources in accordance with the seasons in the Qin Dynasty. ${ }^{9}$

${ }^{6}$ Jin, R. Environmental Law. Peking University Press 1994, p. 47.

${ }^{7}$ See Han FeIzi Collective Interpretation (I), Shanghai People's Publishing House 1974, p. 541.

${ }^{8}$ See China Encyclopedia: Environmental Science. China Encyclopedia Press 1983, p. 502.

${ }^{9}$ See Shuihudi Qin Tomb Bamboo Tube. Cultural Relics Publishing House 1978, p. 26. 
In the later dynasties, there were also some laws and regulations, such as Tang Law, Ming Law, Qing Law, for the protection of natural resources like forests, birds, animals, land, etc.

\subsection{Separation of Environmental Ethics and Environmental Legislation}

However, with the advent of the scientific and technological revolution, human beings have greatly expanded their ability to study the natural world, and their productivity has greatly increased. Environmental ethics and environmental legislation were separated in a sense.

Science and technology is a double-edged sword. It can greatly promote the development of productivity, but it can also cause a devastating blow to nature. On the anthropocentric side, to speak of value really is to hold it in one's mind, where it presents itself as a reason for action or esteem. ${ }^{10}$ Since the industrial revolution, the rapid development of science and technology has rapidly changed our world in a short period of time, creating tremendous material wealth and sustaining the lives of billions of people. However, this development, driven by science and technology, on the one hand, opens up a deeper and broader dimension for the human beings to transform nature. It makes the ability of human beings to take science and technology as the dominant force suddenly emerge as a tremendous force that controls the natural world and objectively causes us to change the surrounding nature and do whatever we want; but on the other hand, the natural environment has been deteriorating as the wheel of human technology rolls by. Natural resources are drying up and the earth groans under the weight of human beings (Chen et al., 2004).

Science and technology revolutions, or industrial revolutions, have brought about the idea of human being winning over nature, which, to a great extent, satisfies human greed to defeat nature. However, the human living environment has been greatly polluted and destroyed by the human beings, and of course, we, human beings, have been retaliated by nature accordingly. The environmental tragedies such as climate change and sea level rise are cases in point. It is time for us to reflect on what we have done. Human beings have to rethink the issue of environmental ethics.

\subsection{The New Combination of Environmental Ethics and Environmental Legislation in the Era of a Community of Shared Future for Mankind}

The evolution of moral and legal consciousness over centuries should now culminate in recognizing the moral importance of natural entities, living and otherwise, for their own sake. ${ }^{11}$ The new combination of environmental law and environmental ethics in the era of a Community of Shared Future for Mankind is a call for international environmental justice. The ethical call for environmental

${ }^{11}$ See Roderick F. Nash, The Rights of Nature: A History of Environmental Ethics 13-32 (1989). 
law has risen to the international scale, not just in the scope of a country. After the combination and separation of environmental ethics and environmental legislation, the current environmental legislation and environmental ethics will combine again, which will be a deeper integration. The new era calls for universal environmental ethics representing global environmental justice, and the concept of a Community of Shared Future for Mankind was born in response to it.

International order and international mechanism have always been closely linked (Liang et al., 1992). International environmental justice, as an ideal international order, must be reflected by international environmental system and mechanism. The practice of international environmental justice is mainly called global environmental governance, which includes the main body of global environmental governance and the mechanism of global environmental governance. As the most important subject of global environmental governance, sovereign nations play a decisive role in the practice of international environmental justice, but on the other hand, due to the existence of individual interests of sovereign nations, sovereign nations are faced with some ethical difficulties when they participate in the practice of international environmental justice. These ethical dilemmas, in today's global environmental governance mechanism, reflect the current situation of the practice of international environmental justice (Sun, 2007).

In the practice of international environmental justice, there are many ethical dilemmas. The existence of these dilemmas may make international environmental justice just remain on abstract principles and not to be truly implemented, which in turn will exacerbate these dilemmas. Therefore, to resolve these difficulties becomes the key to realize the international order of environmental justice, and the concept of a Community of Shared Future for Mankind provides a feasible scheme for the world. The environmental problem is a double-edged sword. On the one hand, it may be an opportunity for the international community to put aside its past dissension, strengthen cooperation and establish a good partnership; on the other hand, it also means that the world's environmental resources and environmental capacity are increasingly limited. It could lead to tensions and instability in international relations (Zhang, 1997). Only with the ethics of a Community of Shared Future for Mankind to address these international environmental dilemmas, the problem of international environmental justice can be solved.

\section{The Ethical Turn of the Rule of Law of Global Environment in the Era of a Community of Shared Future for Mankind}

\subsection{The Structural Transition of International Environmental Law Should Be Realized}

The concept of a Community of Shared Future for Mankind is a scientific plan proposed by China to reform the global governance system. Currently, interna- 
tional law, which underpins global governance, still adheres to nationalism. The pursuit of national values and the realization of national interests as its central mission is weak in dealing with global issues, such as climate change and development imbalances. Therefore, the contemporary international law system is far from what the concept of a Community of Shared Future for Mankind expects the international environmental rule of law to be, so it must undergo structural transition to conform to the concept of a Community of Shared Future for Mankind.

On the structural transition of international environmental law, the concept of a Community of Shared Future for Mankind makes demands and provides guidance. China proposes the building of a Community of Shared Future for Mankind, which provides important conceptual resources for the reform of the global governance system, draws a beautiful blueprint for the development and progress of human society, and will play an important leading role in the improvement and development of the global environmental governance system (Zhang H, 2008).

Large countries are sovereign nations with great influence on a global scale. The failure of international environmental law to effectively improve the rule of law in the global environment is largely due to the fact that contemporary international environmental governance does not substantially increase the responsibilities of large countries. Some large countries are infatuated with the abuse of their own power and the pursuit of their own special interests, and have no sense of responsibility in the area of global environmental governance. Large countries are the largest consumers of global resources and are often the most capable providers of funds and technology. Therefore, in terms of responsibility for global environmental governance, the more powerful the country, the greater the responsibility. Moreover, as a result of the deepening interdependence of countries, with the increase of global challenges, the international community's expectations for countries, especially large countries, to assume more international responsibilities are growing. Therefore, the large countries should focus on the overall situation, lead the trend of the times with their own advantages, and improve the supply and distribution system of global public goods. China's proposal to build a Community of Shared Future for Mankind is itself an important manifestation of a responsible country. Moreover, China is also the practitioner and promoter of a Community of Shared Future for Mankind, including the provision of various kinds of ideas, institutions and funds to the international community through Belt and Road Initiative. International environmental law should, in accordance with the vision and requirements of a Community of Shared Future for Mankind, effectively increase the international responsibilities of large countries (Cai, 2012).

Since there is no world government, global environmental governance must be solved by the cooperation of all countries. All countries have the right not only to consume the global environment as public goods but also to bear the corresponding responsibility. However, because of the profound differences be- 
tween countries, especially in terms of supply capacity, they have shared responsibility for addressing global challenges such as climate change, but the responsibility should be different. This is why the principle of common but differentiated responsibilities has arisen. However, due to the lack of effective international environmental ethics in international environmental law, the principle of common but differentiated responsibilities often has little effect, so international environmental law should realize its structural transformation.

\subsection{The Dilemma of Global Environmental Governance under the Absence of Environmental Ethics}

With respect to policy decisions, then, we face a choice of rationalities. ${ }^{12}$ On 1 June 2017, US President Donald Trump announced his withdrawal from the Paris Accords. In consideration of the interests of revitalizing traditional manufacturing and energy industries, etc., the US government decided to withdraw from the Paris Accords regardless of the general opposition of the international community. It would undoubtedly have a negative impact on the international negotiations on the rules and details of the implementation of the Paris Accords, and would cause widespread concern in the international community. Whether we live by our beliefs or satisfy our interests, ${ }^{13}$ global climate governance may enter into a period of low ebb and its leadership will change or diverge further (Chai et al., 2017). As the US Government ceases to meet its emissions reduction obligations under the Paris Accords, and is no longer committed to financial assistance and technology transfer obligations, the EU and emerging developing countries will come under greater pressure, and the follow-up of the implementation of the principle of common but differentiated responsibilities will be more detrimental to emerging developing countries. History is suggestive, but it need not bear argumentative weight (Richard, 2014). In the face of the Trump Administration's “de-climate" policy, the lack of US global climate governance, other countries, especially the European Union and emerging developing countries such as China, Brazil, India, etc., must adopt a pragmatic approach and should not continue to argue over the concrete interpretation of the principle of common but differentiated responsibilities. Rather, it is more effective in implementing the Intended Nationally Determined Contributions and moving forward towards the goals set by the Paris Accords.

It is true that the reality is not optimistic, and the practice of the principle of common but differentiated responsibilities is by no means a smooth road. To date, the recognition of international environmental responsibility by developed countries has been inadequate. In some international treaties reflecting this principle, some obligations which developed countries made commitments to undertake are mostly empty talks, which has not been fulfilled in essence. There are indications that the legal status of the principle of common but differentiated responsibilities is not particularly firm, that it will take time for it to become an

${ }^{12}$ Sagoff. Conflict and Contradiction, supra note 12 , at 313.

${ }^{13}$ Sagoff. Conflict and Contradiction, supra note 12, at 313. 
international custom, and that it will be urgent for the vast number of developing countries to take further care and to promote the development of this principle through various means. Environmental policy embodied "environmental racism" was an important shot in the arm that helped keep environmental justice alive. The existing evidence of disproportionate impacts was sufficient to identify the problem, and the claims of racism created the public gravitas necessary to raise policymakers' concern and bring everyone to the negotiating table (Richard, 2000). It is undeniable that since the principle embodies the will of developing countries to safeguard their own rights and interests and participate in international negotiations on an equal footing in order to solve global environmental problems, it has a strong affinity for developing countries. The scope of its application is too narrow, mainly confined to the field of international environmental protection. And in the WTO rules, it seems difficult to find its whereabouts.

\subsection{The Path of Global Environmental Governance under the Concept of a Community of Shared Future for Mankind}

Nowadays, the environmental governance of international community mainly includes the problem of responsibility distribution caused by climate governance and the problem of global waste (garbage) treatment. These problems have not been solved fundamentally for a long time, which reflects the lack of environmental ethics in international environmental legislation from one aspect.

\subsubsection{The Governance of Climate Change Issues}

In the face of the worsening of global environmental problems and the global climate change, many countries are often unwilling to take on their own responsibilities and ignore the holistic characteristics of global environmental problems. The principle of common but differentiated responsibilities in global climate governance faces great challenges.

In general, differences between developing and developed countries still exist on the issue of climate change. Firstly, it is about the essence of climate change. Developed countries regard climate change as an environmental problem in which man is the perpetrator and nature is the victim. Despite the negative effects of climate change on humans, we are just taking consequences of our own actions. From this premise, they believe that environmental integrity is the primary goal of mankind. The most effective way to achieve this goal is for all countries to participate in global greenhouse gas emission reductions, or for developing countries to participate in the process of controlling greenhouse gas emissions. And developing countries have very different views. They deem climate change as a development issue. In this case, the victim is not nature but man. In most developing countries, agriculture accounts for a considerable proportion of their industrial structure. Natural disasters such as sea level rise, drought, desertification, floods and storms caused by climate change not only have a serious impact on agricultural production, but also increase the preva- 
lence of diseases. According to the World Bank, from 1990 to $1998,94 \%$ of the world's natural disasters and $97 \%$ of deaths from natural disasters occurred in developing countries. From 1980 to 2002, fewer than $0.1 \%$ of the population in the United States was homeless as a result of natural disasters caused by climate change, compared with $45 \%$ in Bangladesh. ${ }^{14}$ So, for developing countries, they are victims of climate change, and developed countries are the makers of the problem. It is generally agreed that the main way to deal with climate change is mitigation and adaptation. For developing countries, mitigation, adaptation and development are closely linked, and development is their best form of adaptation and mitigation to climate change. Therefore, the more fully developed, the more effective the response to climate change will be.

Secondly, developed and developing countries have different views on what climate justice is. Developed countries, based on the efficiency in addressing climate change, believe that all countries must participate, so climate justice is how to equitably distribute the reduction of emissions among all countries. In contrast, in view of the causes and consequences of climate change, developing countries believe that developed countries, by emitting large quantities of greenhouse gases, have developed themselves while creating climate change problems. Developing countries, with smaller emissions, are the biggest victims of climate change. According to the third assessment report of IPCC, even if the Kyoto Protocol is fully implemented, still the impact of global climate change will gradually become apparent in the coming decades. Because the impact of climate change is not only related to the intensity of climate change, but also to the ability of a country or region to adapt to this change. Overall, developed countries are less affected by climate change. Thus, the primary injustice for developing countries is the unfair distribution of the burden caused by the effects of climate change. Therefore, developed countries should compensate for all the damages that developing countries are suffering and will suffer from climate change (Tan, 2010).

With regard to the problems arising from the governance of climate change, firstly, the major powers led by the United States should bear the responsibilities, and they should not withdraw from the relevant global environmental governance conventions that have been reached. The reason why some large countries withdraw from the conventions on the global environment is because of short-term interests and a narrow vision. It has been forgotten that centuries of industrial development have come at the expense of atmospheric pollution to the environment of developing countries, but now they are talking with developing countries about equitable sharing of global climate governance, which is in fact an issue of international environmental justice. It is necessary to perfect the global environmental governance from the perspective of the environmental ethics of a Community of Shared Future for Mankind so that environmental ethics and environmental law are more closely combined in the new period. ${ }^{14}$ Tan, Y. Dilemma of Global Climate Governance and Its Historical Causes. Hubei Social Sciences, 2010 (6): 123-125. 
Therefore, to solve the problem of climate change governance in the international community, developed countries should not talk to developing countries about fair sharing of responsibilities in terms of absolute value of responsibility-sharing. Countries are different in size and in different levels of development, and the degree of emission in the process of industrialization is also different. Some large countries in the developed countries should enrich themselves with the environmental ethics of a Community of Shared Future for Mankind, and, as great powers, they should offer to take on their environmental responsibilities.

Secondly, the developed countries should make full use of their own financial and technological strength to help the vast number of developing countries to improve their environmental governance capacity, and relax the export control of high-tech products and equipment so that the development of the developed countries can benefit the developing countries. Then the production and life of the developing countries can be more conducive to environmental protection. Objectively speaking, China's Belt and Road Initiative is exactly done under the guidance of the concept of a Community of Shared Future for Mankind. The extension of its capital and advanced technology to other countries without conditions will surely benefit the development of the people of the world.

Thirdly, it is also necessary to perfect the refugee convention in a timely manner. How the large countries in developed and even developing countries can better accept refugees caused by global climate problems should be taken into account so as to better protect international environmental refugees. After all, these environmental refugees are not created because of their own industrialization process causing environmental pollution and climate change, therefore, the acceptance of environmental refugees is a manifestation of international justice.

In a word, the climate problem is a global problem, and the developed countries are not immune to environmental degradation without taking responsibility. It will ultimately infringe upon their own environmental rights and interests. Only by adhering to the concept of a Community of Shared Future for Mankind, working together with developing countries, and taking the initiative to take on more environmental governance capabilities can developed countries better solve the environmental governance problems and ultimately benefit themselves.

\subsubsection{The Treatment of Waste Export Problems}

The Basel Convention on the Control of Transboundary Movements of Hazardous Wastes and Their Disposal, which came into force on 5 May, 1992, is the main international legal basis for the international community to oppose foreign waste (garbage). All major exporters of waste, except the United States, are the acceding countries. China signed the Basel Convention in 1990. The Basel Convention aims to curb the transboundary movement and illegal disposal of hazardous wastes and establish the general principles of waste control (Zhang, 2014). Social regulation reflects public values we choose collectively, and these

${ }^{15}$ Sagoff, Economy, supra note 14, at 16-17; see also Sagoff, Conflict and Contradiction, supra note 12 , at 286 . 
may conflict with wants and interests we pursue individually. ${ }^{15}$ However, in developed countries, the export of waste is not strictly controlled, and a large number of unsterilized waste that has not been sorted has been pouring into developing countries. China has become the largest importer of foreign waste, and a large amount of unrecyclable domestic waste has entered China and other developing countries by means of false declaration of goods' names as well as other illegal means, which has brought tremendous environmental disasters to China and other developing countries.

According to the Huzhou City News, on 9 April, 2018, Huzhou Customs of Zhejiang seized an amount of foreign waste with excessive inclusions. This shipment of foreign waste, weighing 469 tons and with 40 containers in total, was sent from the United States to the customs port and then transferred to Huzhou's Anji Port Container Terminal. Huzhou Customs found that the waste paper not only smelled pungent but also contained a large number of used clothes, metals, waste beverage bottles and other inclusions. After identification, the content of inclusions reached 5.28\%, which seriously exceeded the standard of environmental protection for imported solid waste used as raw materials in China. The inclusions should not be more than $0.5 \%$. April was during the rainy spring season, and the temperature was rising rapidly, which was the right time for the propagation of bacteria. In addition, the waste paper and other inclusions had a pungent smell, so they surely would pollute the local environment for as long as it stayed at the wharf. ${ }^{16}$

The result of the export of waste from developed countries to developing countries is that, on the one hand, developing countries, such as China, in order to seek economic growth, their resources have to be exported to developed countries continuously, resulting in local environmental damage because of undeveloped environmental protection technologies, and on the other hand, they have to absorb the foreign waste from developed countries.

Due to the absence of standardized inspection and quarantine procedures and treatment processes, foreign waste has caused serious pollution. The gas, biochemistry, heavy metals and other hazards from foreign waste cause harm to the environment for a long time, which not only endangers the health of relevant practitioners in the chain of foreign waste industry but also causes pollution to soil, water, environment and ecology in large area.

This is an unclad international environmental justice issue, and this situation must be reversed. Otherwise, in the short term, the environmental problem will harm the environment of developing countries, but eventually it will hurt developed countries as well. Because, as a whole, the air, water, etc. in the environment are flowing, no country can be left alone.

Developed countries themselves should deal with their own waste, classify it and recycle it, but not keep exporting it to developing countries. Do not export waste to other countries and create environmental pollution, or one day, the ${ }^{16}$ Huzhou Customs Seized a Great Number of Inclusions Seriously Exceeding the Standard in Waste Import. Available online: http://zj.qq.com/a/20180411/012296.htm (accessed on 1 June 2018). 
pollution will hurt themselves, too.

\section{Conclusion}

The protection of the environment relates to the future and destiny of mankind and affects every country and individual in the world. People in different countries and regions have different views on environmental ethics because of different ideologies. The earth is an interconnected whole. The environment has no national boundaries, and the protection of the global environment is the common task of all countries in the world. Only through extensive and effective international cooperation can it be accomplished (Lin, 2011). As far as the field of international law is concerned, the concept of a Community of Shared Future for Mankind reflects China's new understanding of the social foundation of international law in the 21 st century, and is a complement and development to the previous concept of "international society" and "international community" (Zhang H., 2008). The concept of a Community of Shared Future for Mankind is a reexamination of international justice. In the aspect of international environmental governance, the concept of a Community of Shared Future for Mankind is actually the newest environmental ethical achievement of international environmental law and the latest interpretation of international environmental justice. It is not only the historical experience summary of human survival wisdom but also the rational thinking to solve the common predicament of human development. By seeking "us" between "you" and "me", we human beings can establish a peaceful development, mutually beneficial and win-win international relation, and construct a common discourse system and value pursuit between Chinese and other cultures. After the combination and separation of environmental ethics and environmental legislation, it is necessary for people all over the world to come to an ethical turn for a global perspective. The concept of a Community of Shared Future for Mankind can be of great significance to realize environmental governance among countries, to solve the problem of climate change and waste export, and to realize international environmental justice under the new situation.

\section{Conflicts of Interest}

The authors declare no conflicts of interest regarding the publication of this paper.

\section{References}

Barry, B. (2011). Theories of Justice (pp. 1-6). In X. Sun, et al. (Trs.), Jilin: Jilin People's Publishing House.

Cai, C. (2012). Problems of Great Powers in International Law. Chinese Journal of Law, 6, 199-206.

Chai, Q., Fu, S., et al. (2017). The Impact of Trump's “De-Climate” Policy on Global Climate Governance Population. Chinese Journal of Population Resources and Environment, $8,1-8$.

Chen, Q., et al. (2004). Basic Theory of Environmental Law. Beijing: China Environmen- 
tal Science Press.

Li, P. (2014). Subversion of Ethical Extensionism: A Study of Western Environmental Ethical Trend of Thought. Changsha: Hunan Normal University Press.

Liang, S., et al. (1992). International Political Theory. Beijing: Chinese People's Public Security University Press.

Lin, C. (2011). International Environmental Law (Revision). Beijing: People's Publishing House.

Liu, K., Yuan, W., Luo, J., \& Chu, Y. (2012). Sea-Level Rise: A Quietly Occurring Marine Disaster. Marine Information, 3, 31-39.

Mao, Y. (2014). Public International Law Issues of Climate Refugees and Solutions. Journal of Jilin Public Security Academy, 2, 73-79.

Richard Jr., H. F. (2014). How to Make Sense of Supreme Court Standing Cases: A Plea for the Right Kind of Realism, 23 WM. \& MARY BILL RTS. J.

Richard, J. L. (2000). Environmental Racism! That's What It Is. 2000 U. ILL. L. REV.

Sun, F. (2007). Research on the Main Problems of Global Environmental Governance. Jinan: Shandong University.

Tan, Y. (2010). Dilemma of Global Climate Governance and Its Historical Causes. Hubei Social Sciences, 6, 123-125.

Zhang, H. (1997). New Trends in Environmental Diplomacy in the United States. Beijing: World Affairs Press.

Zhang, H. (2018). A Community of Shared Future for Mankind: The Contemporary Development of the Social Foundations Theory of International Law. Social Sciences in China, 5, 43-68.

Zhang, H. (2018). Building a Community with a Shared Future for Mankind: China's View of International System in the New Era. International Law Review of Wuhan University, 1, 20-34.

Zhang, J. (2014). Study on the Strategy of Coping with Foreign Garbage in China under the Background of Industry Moving Westward. Probe. 